Tikal Report No. 25B

THE CERAMIC SEQUENCE OF TIKAL 


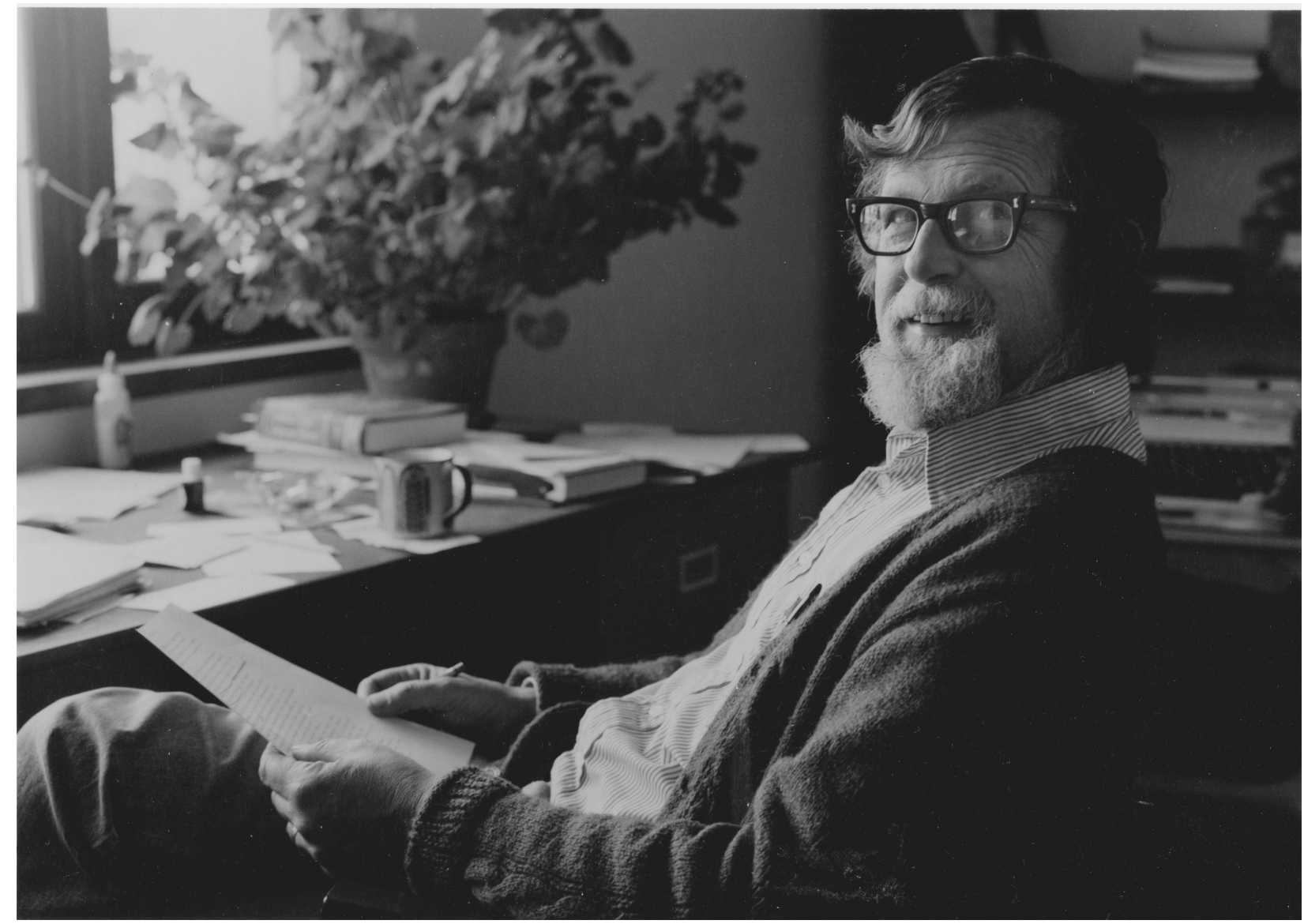

Frontispiece. Pat Culbert in Santa Fe, NM 1982.

(Photograph courtesy of Bobbi Culbert.) 
University Museum Monograph 152

Tikal Report No. 25B

\section{THE CERAMIC SEQUENCE OF TIKAL}

By T. Patrick Culbert

and

Laura J. Kosakowsky

Content editor: Hattula Moholy-Nagy

Series Editors

William A. Haviland

Simon Martin

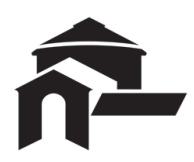

Published by

UNIVERSITY OF PENNSYLVANIA MUSEUM

of Archaeology and Anthropology

Philadelphia

2019 
Library of Congress Cataloging-in-Publication Data

Names: Culbert, T. Patrick, author. | Kosakowsky, Laura J., author. |

Moholy-Nagy, Hattula, editor.

Title: The ceramic sequence of Tikal / by T. Patrick Culbert and Laura J.

Kosakowsky ; content editor, Hattula Moholy-Nagy.

Description: Philadelphia : University of Pennsylvania Museum of Archaeology

and Anthropology, 2019. | Series: University museum monograph ; 152 |

Series: Tikal report ; No. 25B | Includes bibliographical references.

Identifiers: LCCN 2019014200| ISBN 9781949057034 (hardcover : alk. paper) |

ISBN 1949057038 (hardcover : alk. paper)

Subjects: LCSH: Tikal Site (Guatemala) | Maya pottery. |

Pottery--Guatemala--Tikal Site--Classification. |

Pottery--Guatemala--Tikal Site--Themes, motives. | Mayas--Antiquities. |

Excavations (Archaeology)--Guatemala.

Classification: LCC F1465.1.T5 C85 2019| DDC 972.81/01--dc23

LC record available at https://lccn.loc.gov/2019014200

(C) 2019 by the University of Pennsylvania Museum of Archaeology and Anthropology Philadelphia, PA

All rights reserved. Published 2019

Distributed for the University of Pennsylvania Museum of Archaeology and Anthropology by the University of Pennsylvania Press.

Printed in the United States of America on acid-free paper. 